ENTREPRENEURSHIP AND SUSTAINABILITY ISSUES

ISSN 2345-0282 (online) http://jssidoi.org/jesi/

2019 Volume 7 Number 2 (December)

http://doi.org/10.9770/jesi.2019.7.2(54)

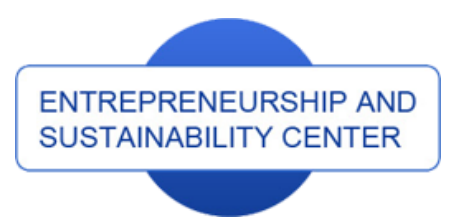

Publisher

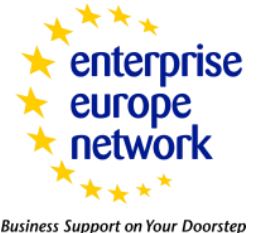

CASPA
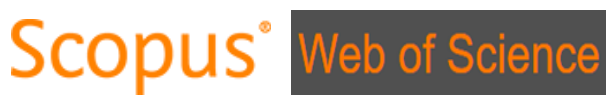

http://jssidoi.org/esc/home

Clarivate
Analytics

\title{
ECONOMIC LEVERS OF REGULATION OF ENTREPRENEURSHIP
}

\section{Roza Shokan $^{1}$, Ainur Karipova ${ }^{2}$, Aizhan Khoich ${ }^{3}$, Gulmira Kabdullina ${ }^{4}$, Nuradin Kudaibergenov ${ }^{5}$, Gaukhar Niyetalina ${ }^{6}$}

\author{
1,2,3 L.N.Gumilyov Eurasian National University, Satpayev 2 street, Astana, Kazakhstan \\ ${ }^{4}$ South Ural State University (National Research University), Chelyabinsk, Lenin Avenue 76, Russia \\ ${ }^{5}$ Kazakh Ablai Khan University of International Relations and World Languages, Muratbayeva 200 Street, Almaty, \\ Kazakhstan \\ ${ }^{6}$ «Turan» University, Dostyk Avenue 108, Almaty, Kazakhstan \\ E-mails: ${ }^{1}$ Roza-shokan@mail.ru ; ${ }^{2}$ karipovaainur@mail.ru ; ${ }^{3}$ ayjika@yahoo.com; ${ }^{4}$ Asilhan1996@mail.ru; \\ ${ }^{5}$ kanur1312@mail.rú6 g.niyetalina@turan-edu.kz
}

Received 10 March 2019; accepted 10 October 2019; published 15 December 2019

\begin{abstract}
The article discusses the current state of small and medium-sized businesses in the country, analyzes the problems hindering its development, presents the author's vision of their solution. The authors explore the sources of financial support for the development of entrepreneurship, the problems of their insufficiency, lack of incentives for implementation. Based on the analysis of business activities in Kazakhstan in recent years, conclusions and recommendations have been formulated for improving the economic instruments for regulating entrepreneurship in Kazakhstan, and a forecast has been given for the further development of SMEs. The policy of industrialinnovative development of the economy does not give the desired result, the innovative component of the products produced still remains at a very low level, the competitiveness of the products produced is at a low level also.
\end{abstract}

Keywords: small business; tax incentives; financial support; financial security

Reference to this paper should be made as follows: Shokan, R., Karipova, A., Khoich, A., Kabdullina, G., Kudaibergenova, N., Niyetalina, G. 2019. Economic levers of regulation of entrepreneurship. Entrepreneurship and Sustainability Issues, 7(2) 1567-1581. http://doi.org/10.9770/jesi.2019.7.2(54)

JEL Classifications: M21, M38

\section{Introduction}

This is explained by the fact that the country's industrial-innovative policy is carried out without sufficient institutional changes in the business environment, the scientific and educational system, legislation, government and other areas. In order to achieve fundamental modernization and competitiveness, large-scale investments are needed in non-primary industries. Concentration of state and business resources in the breakthrough areas of growth of innovative activity will increase the competitiveness of domestic products, develop new market niches 


\section{ENTREPRENEURSHIP AND SUSTAINABILITY ISSUES}

ISSN 2345-0282 (online) http://jssidoi.org/jesi/

2019 Volume 7 Number 2 (December)

http://doi.org/10.9770/jesi.2019.7.2(54)

and accelerate the pace of economic growth. In modern conditions, the functioning of entrepreneurship is of particular importance, ensuring employment of the population, prompt satisfaction of the needs in the production of goods, food and services. In the Message of the President of the Republic of Kazakhstan N.Nazarbayev to the people of Kazakhstan dated January 31, 2017, "The Third Modernization of Kazakhstan: Global Competitiveness" states "The second priority is the cardinal improvement and expansion of the business environment. One of our strategic goals is to ensure by 2050 the contribution of small and medium-sized businesses to the country's GDP of at least 50" (Nazarbayev 2017).

\section{Research background}

At the same time, the further effective development of small and medium-sized businesses in Kazakhstan is constrained by significant shortcomings of both non-financial and financial nature. The last and most important ones include the insufficient volumes of own sources of financial support, a small share of forms of state financial support and unavailability of crediting.

Turning to the practice of developed countries, it is worth noting that the development of SMEs in foreign countries is proceeding at a faster rate than in Kazakhstan. Today, in the most developed foreign countries, SME companies account for about 70-90\% of the total number of enterprises. In the US small and medium-sized business sector, approximately $53 \%$ of the working-age population work in Japan, the figure is $71.7 \%$, and in the European Union (EU) countries, about $50 \%$ of the working civilian population work in small enterprises. In addition, in the EU countries, medium-sized enterprises make up only $1 \%$ of the total number of enterprises, while providing about $20 \%$ of the total turnover of enterprises and $17 \%$ of the total employment of the population (Babich 2016; Kowo et al. 2019).

As the analysis of the experience of developed countries shows, the state plays an important role in creating favorable conditions for stimulating innovative activity in all sectors of the economy (Mamedov et al., 2016; Cichy and Gradoń, 2016; Baltgailis, 2019).

The state provides both direct support for innovation (selection of priority areas for the development of science and technology, financing from the state budget) (Zizlavsky, 2016; Vaculík et al., 2017) and indirect support (using fiscal methods, legislative regulation, creating favorable conditions for the commercialization of scientific knowledge) (Krpálek et al., 2016; Ivanová and Masárová, 2016; Newman et al., 2018).

As a result, the pivotal goal of the SME support policy implemented within the European Union is to balance the interests of business and the state, ensure rational conditions for business, and increase the competitiveness of SMEs. The unique system of support and regulation of small business in Europe began to emerge as early as the 1970s, and continues to emerge through the introduction of various programs and the creation of support funds for the IB. At present, the key directions of the European Union's policy regarding the development of small business are:

- financial support for SMEs;

- simplification of the legal framework, administrative procedures in the field of small business support;

- participation of associations that represent the interests of small and medium-sized businesses in decision making within the framework of the EU;

- assistance to SMEs in the field of innovation, research and training;

- elimination of violations in the functioning of the "single market" and competition, reducing the effectiveness of SMEs;

- increasing the competitiveness of SMEs, in particular, in order to enter the foreign market;

- cultivating entrepreneurship among EU citizens and supporting various forms of cooperation between SMEs.

The current state of small and medium-sized businesses in Kazakhstan is characterized by intermittent trends 
(Figure 1).

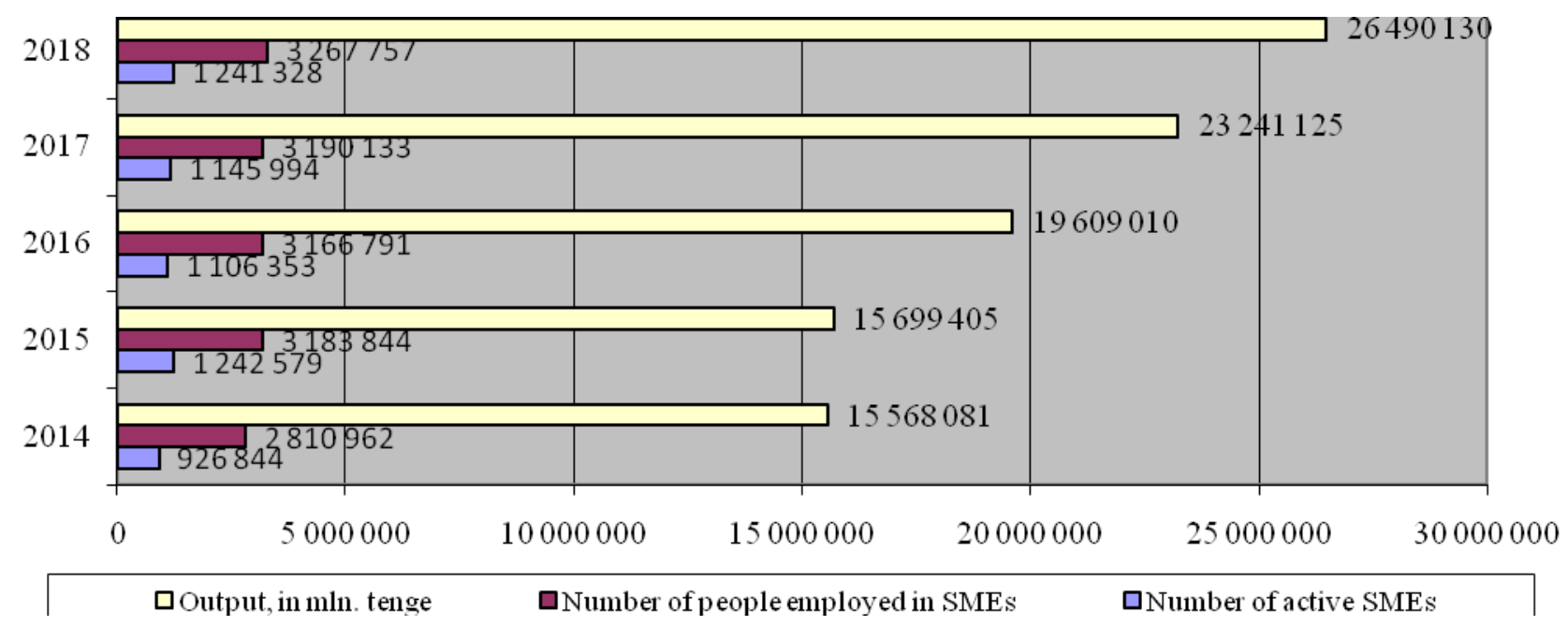

Figure 1. Dynamics of development of small and medium-sized businesses in Kazakhstan Source: compiled by authors according to Committee of Statistics of the Ministry of National Economy, http://www.stat.kz

According to the results of the analysis, in the structure of active SME entities, according to the organizational and legal forms, the entities that carry out entrepreneurial activities without forming a legal entity prevail individual entrepreneurs, whose number in 2017 is 747.1 thousand units $-65.2 \%$ of the total active subjects. The number of FH - 187.5 thousand or $16.4 \%$, small and medium enterprises -211.3 thousand units or $18.4 \%$ of the total number of active small and medium-sized businesses (Table 1).

Table 1. Structure of active SMEs by organizational legal forms

\begin{tabular}{|c|c|c|c|c|c|c|}
\hline \multirow{2}{*}{ Type of ownership } & \multirow{2}{*}{2015} & \multirow{2}{*}{2016} & \multirow{2}{*}{2017} & \multicolumn{3}{|c|}{ Share of total active subjects, in \% } \\
\hline & & & & 2015 & 2016 & 2017 \\
\hline Individual entrepreneurs & 882849 & 736121 & 747107 & 71,0 & 66,5 & 65,2 \\
\hline Peasant farms & 181154 & 177884 & 187527 & 14,6 & 16,1 & 16,4 \\
\hline Small and medium enterprises & 178576 & 192348 & 211360 & 14,4 & 17,4 & 18,4 \\
\hline Total active subjects & 1242579 & 1106353 & 1145994 & 100 & 100 & 100 \\
\hline
\end{tabular}

Source: compiled by authors

The proportion of the population actively engaged in small business in 2017 was $40.8 \%$ of the total number of people employed in the domestic economy. The dynamics of this indicator for the period from 2013 to 2017 has the following trend: for example, the share of the population actively engaged in SMEs in 2017 by 2013 increased by $23.8 \%$, and by 2016 it increased by $0.7 \%$.

The structure of small businesses in the sectors of the country's economy is an important indicator of the qualitative development of the private entrepreneurship sector and the economy as a whole. The analysis allows to draw the following conclusions (in accordance with table 2). 
Table 2. Estimation of small and medium-sized businesses by industry for 01.01 .2018

\begin{tabular}{|c|l|c|c|c|}
\hline \multirow{2}{*}{ № } & \multicolumn{1}{|c|}{$\begin{array}{c}\text { Industry } \\
\text { number of registered SMEs in the } \\
\text { industry, in \% }\end{array}$} & $\begin{array}{c}\text { Number of } \\
\text { employees, in \% }\end{array}$ & Output, in \% \\
\hline 1 & Agriculture & 19,4 & 13,1 & 7,8 \\
\hline 2 & Industry & 3,7 & 10,1 & 20,3 \\
\hline 3 & Construction & 4,5 & 8,9 & 17,1 \\
\hline 4 & Trade & 35,6 & 29,1 & 23,7 \\
\hline 5 & Ansport and warehousing & 6 & 5,6 & 5,9 \\
\hline 6 & Others & 30,8 & 33,2 & 25,2 \\
\hline
\end{tabular}

Source: compiled by authors

As can be seen from the data presented, the share of active SMEs by industry in 2017 is as follows: agriculture $19.4 \%$, trade $35.6 \%$, transport and warehousing $6 \%$. The largest share in the total volume are trade and communication enterprises, and the smallest industry.

Next, we will analyze small and medium businesses by region in 2017 (Table 3).

Table 3. Estimation of small and medium business in the context of the regions of the Republic of Kazakhstan for 01.01 .2018

\begin{tabular}{|l|l|l|}
\hline \multicolumn{1}{|c|}{ Region } & The number of active SMEs, \\
in units & $\begin{array}{c}\text { Share of active SMEs in the total number of } \\
\text { registered SMEs in Kazakhstan, in \% }\end{array}$ \\
\hline Republic of Kazakhstan & 211360 & 100,0 \\
\hline Akmola & 6551 & 3,1 \\
\hline Aktobe & 9133 & 4,3 \\
\hline Almaty & 8779 & 4,2 \\
\hline Atyrau & 6119 & 2,9 \\
\hline West Kazakhstan & 5597 & 2,6 \\
\hline Zhambyl & 5282 & 2,5 \\
\hline Karaganda & 16288 & 7,7 \\
\hline Kostanay & 6761 & 3,2 \\
\hline Kyzylorda & 4887 & 2,3 \\
\hline Mangystau & 7498 & 3,5 \\
\hline South Kazakhstan & 16686 & 7,9 \\
\hline Pavlodar & 8583 & 4,1 \\
\hline North Kazakhstan & 4829 & 2,3 \\
\hline East Kazakhstan & 10058 & 4,8 \\
\hline Astana city & 35590 & 16,8 \\
\hline Almaty city & 58719 & 27,8 \\
\hline
\end{tabular}

Source: compiled by authors

Review of the number of active SMEs by region in 2017 showed that the largest number was located in Almaty (58.7 thousand units), Astana (35.6 thousand units). A smaller number of active SMEs in Kyzylorda (4.9 thousand units). Of all registered SMEs, about 55\% are active, i.e. carry out ongoing activities and submit reports to the statistical authorities.

Summing up, we note that as of May 2018, the Republic of Kazakhstan among the countries of the world, according to the favorable conditions for doing business, ranked 28th according to the World Bank DoingBusiness rating. According to such indicators as "registration of enterprises", "registration of property" and 


\section{ENTREPRENEURSHIP AND SUSTAINABILITY ISSUES}

ISSN 2345-0282 (online) http://jssidoi.org/jesi/

2019 Volume 7 Number 2 (December)

http://doi.org/10.9770/jesi.2019.7.2(54)

"taxation", Kazakhstan took 36, 18 and 56 places, respectively. It is also worth noting that over the past 3 years, the position of the Republic of Kazakhstan has steadily increased from 80 to 28 (Statistics Committee 2018).

\section{Methodology}

At the same time, despite the positive development trend of small business, as a result of the analysis, the Republic of Kazakhstan is lagging behind in terms of the development parameters of SMEs from foreign countries. It should be noted that the main factors hindering the development of this sector according to the results of monitoring conducted by the Economic Research Institute are:

- imperfection of tax policy;

- instability of the general economic situation in the country;

- low level of solvency of the Kazakhstan population;

- lack of working capital;

- low competitiveness of SMEs;

- interaction with government bodies;

- lack of qualified personnel;

- insufficient number of financial and scientific institutions;

- insufficient financial support and state financial support;

- unavailability of credit funds.

The latter factors are the most important, since it is the state that should support the development of private entrepreneurship. The small business sector is characterized by an increased level of risk, as a result of which many commercial banks themselves do not risk lending to SMEs. In addition, it should be noted that the refinancing rate set by the National Bank is very heavy for many SMEs (Bulatov 2018).

In international practice, it is considered normal when about $90 \%$ of credit funds are issued under state guarantees. In our country, there is also a system of state lending, which is an indispensable attribute of all government programs to support small and medium businesses. However, it was noted that its volume is not enough to cover the needs of SMEs.

The analysis allows us to conclude that the main sources of financing are the own funds of the founders of small enterprises $-21.7 \%$ and the profit obtained as a result of the business activity - 67.0. However, own funds are often not enough, and the lack of financial support can be felt both at the initial stage of business development and in the process of business development. In connection with what enterprises require borrowed funds, but according to the results of the analysis revealed that their share is significant small and is only $25.5 \%$. At the same time, bank loans occupy only $9.4 \%$. $21.7 \%$ of enterprises do not have opportunities for development. Small business support is the cornerstone of government policy. This is enshrined in such fundamental documents as the "Strategy of Kazakhstan - 2050". Issues of further strengthening the business environment are given exceptional attention in the annual Presidential Address to the people of Kazakhstan.

Today in the field of private entrepreneurship there are a number of economic problems, which from the point of view of entrepreneurs themselves include:

- high tax burden (47\%);

- limited financial resources $(46 \%)$;

- corruption in government (32\%);

- difficulties in obtaining a loan $(25 \%)$;

- staff qualification $(12 \%)$;

- problems associated with the registration of the business itself (11\%)

Financial problems manifest, above all: 


\section{ENTREPRENEURSHIP AND SUSTAINABILITY ISSUES}

ISSN 2345-0282 (online) http://jssidoi.org/jesi/

2019 Volume 7 Number 2 (December)

http://doi.org/10.9770/jesi.2019.7.2(54)

- in the absence of financial assets to meet their own investment and negotiable needs;

- in reducing the effective demand for products of SMEs;

- in the absence of funds, due to a significant reduction in turnover of small companies;

- in the growth of overdue accounts payable of enterprises to commercial banks, leasing companies and counterparties in the absence of a system for its restructuring;

- in the absence of access to credit in commercial institutions (due to tougher conditions and an increase in interest rates on loans).

Due to the difficulty of obtaining loans today in Kazakhstan operates the National Fund "Damu", whose main goal is to support small businesses.

The growth of the degree of financial support for small and medium-sized businesses is possible through the use of new financial and organizational resource-saving technologies, in particular, the introduction of elements of operational management accounting, factoring, forfeiting, as effective financial technology methods, leasing, outsourcing, franchising, the use of venture capital, cluster approach as modern forms of small business organization (Aimurzina 2015).

Improving the effectiveness of financial management for SMEs should be carried out through the improvement and implementation of financial asset management systems, namely, the establishment of an accounting system, optimization and short-term planning, as well as control, in order to improve the financial sustainability of small and medium-sized businesses (Khusainov and Isokov 2012).

The cluster approach for small and medium-sized businesses is one of the new and promising forms of cooperation in the Kazakh economy. However, its large-scale and successful implementation is possible only within the framework of the state strategy for the development of the national economy (Kaldybaev and Bayzakov 2017).

The development of public-private partnerships must be built on the basis of a concise legal framework. The state should create a transparent and understandable environment for the early large-scale implementation of resourcesaving innovative methods, in order to increase the share of SMEs in GDP corresponding to developed countries.

At the same time, we can note a number of general recommendations that can assist in the development of entrepreneurship in the Republic of Kazakhstan: fiscal policy, that is, the policy in the field of legal expenses and taxes. It is necessary to make adjustments to the Tax Code of the Republic of Kazakhstan on taxation of strategic industries. Enterprises with problems in the implementation of projects, because of their novelty, should have certain preferences in the field of taxation. To date, only those enterprises that are located in the FEZ have these benefits;

- monetary policy;

- income policy;

- social politics;

- state regulation of pricing;

- foreign economic regulation.

The main economic levers are:

- regulation of the discount rate (discount policy implemented by the National Bank);

- establishing and changing the size of the minimum reserves that financial institutions of the country are obliged to keep in the National Bank;

- operations of state institutions in the securities market, such as the issuance of government obligations, their trade and their redemption. 


\section{ENTREPRENEURSHIP AND SUSTAINABILITY ISSUES}

ISSN 2345-0282 (online) http://jssidoi.org/jesi/

2019 Volume 7 Number 2 (December)

http://doi.org/10.9770/jesi.2019.7.2(54)

Direct state economic regulation is carried out by means of budget policy (Aimurzina, Kamenova and Omarova 2018).

The main instrument for raising funds to cover public spending is taxes. Taxes in state regulation of the economy play two roles:

- the main source of financing public spending;

- regulation tool.

In general, the main tasks of state support of financial support for entrepreneurship should be:

- provision of collateral for the obligations of business entities based on credit agreements (leasing, loan agreements, bank guarantees, etc.) in the form of a guarantee;

- maximum satisfaction of the needs of entrepreneurship in credit resources and the provision of financial support; - financial support of state programs for support and development of entrepreneurship by accumulating budget funds and revenues from own activities;

- increase in the volume of collateral for the obligations of business entities of Kazakhstan (support infrastructure organizations) based on loan agreements (leasing, loan agreements, bank guarantees, etc.) in the form of a guarantee;

- stimulation of banking services for private entrepreneurship due to the system of control over the execution of the tasks facing each of the Banks - Participants of the program;

- ensuring the implementation of obligations under the signed contracts of guarantee (Aimurzina and Kamenova 2017).

Directions of state financial support for SMEs at the regional and local levels should include:

- preferential loans;

- direct financial subsidies;

- Selective loan guarantee

- granting tax exemptions;

- transfer of a part of state property to the SME entity;

- the provision of profitable regional government orders;

- simplification of registration and licensing activities;

- economic and legal preferential consulting.

The central task facing the state is to form a coherent and transparent system of state policy in the field of financial support for small and medium-sized businesses. Such a system cannot be formed without developing and introducing into practice a mechanism for the separation of powers between the government bodies of the Republic of Kazakhstan.

Consequently, only with an integrated approach that takes into account the specifics of the region, but also at the same time, based on their national principles and priorities, it is possible to achieve the desired positive results in the field of SME development and achieve its financial sustainability and stability. Here we can highlight the following measures (Figure 2). 


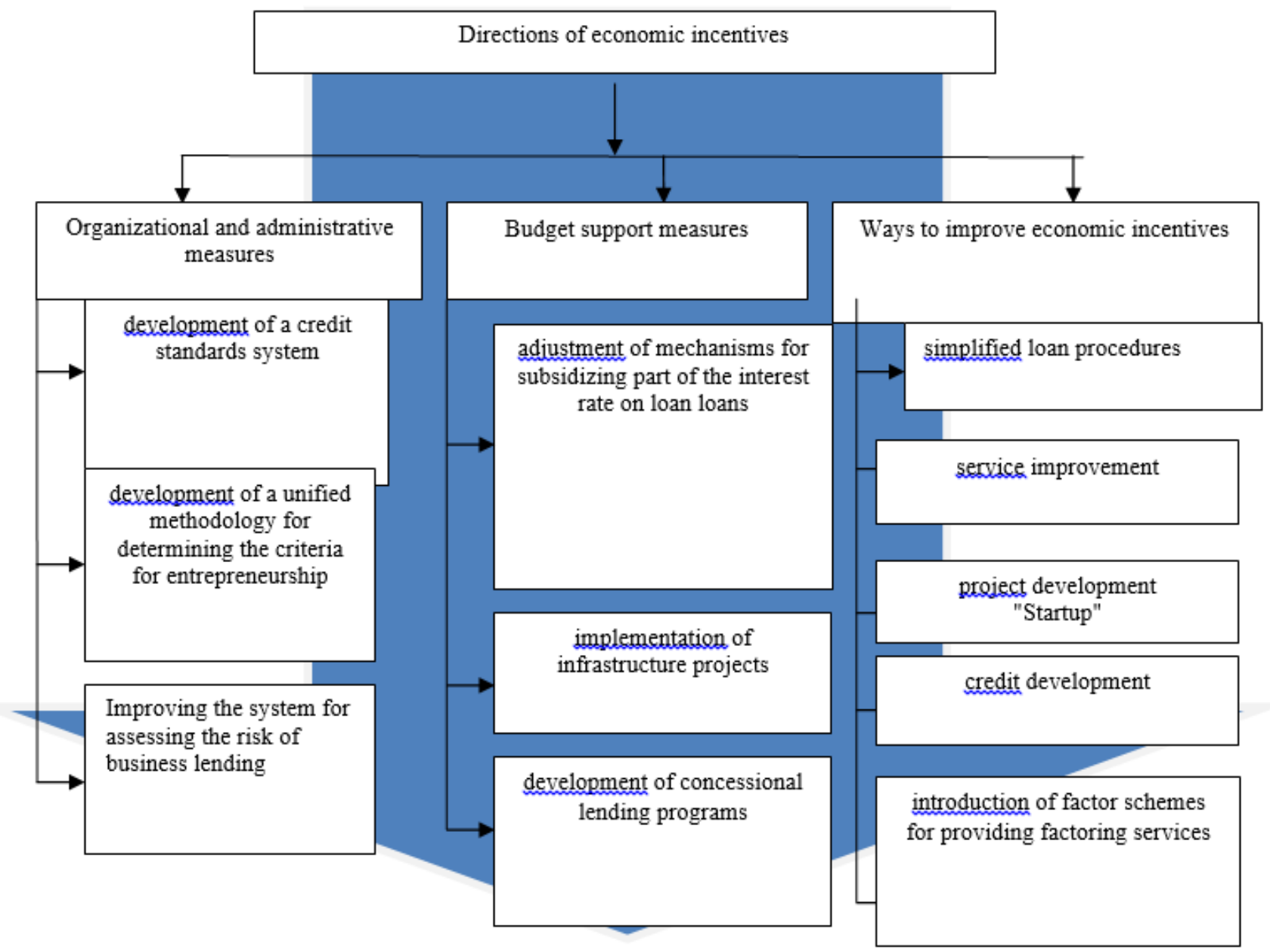

Figure 2. Directions of economic incentives for entrepreneurship Source: compiled by authors

Within the framework of measures for financial provision of small and medium-sized business entities at the local level it is advisable:

- to develop a program of preferential loans;

- to create a guarantee fund to support small innovative businesses, which will help reduce the risks of lending to this category of business entities and increase the effectiveness of the use of funds accumulated to support them;

- to provide support through the provision of support to organizations focused on supporting entrepreneurship;

- to stimulate the development of leasing activities;

- to expand the information system (conditions for obtaining financial support as part of the implementation of business support programs);

- to establish a system of tax incentives for business enterprises, providing, under conditions stipulated, for example, such as large capital investments, reinvestment of profits in R \& D, insurance, etc.

Today, the best way to develop high-tech productions of competitive products with high added value in Kazakhstan is to actively attract strategic foreign investors (companies) from highly developed countries to establish their subsidiaries or branches in our country, they have extensive experience in developing such 
industries abroad. , they do not need to be called for the production of competitive products, they have better management, they have broad access to innovations, high technologies, good of established economic ties, a great experience in a competitive environment, competitive market - their element (Skala 2012).

Only they can facilitate and accelerate the process of introducing the Kazakhstani economy to high technologies, establishing production of products with high value added competitive in foreign markets. They can bring not only the knowledge and experience of business, high technology, effective management, but also cheap long-term money, which is so badly lacking for domestic private business. They will help accelerate the development of domestic highly professional entrepreneurs, especially if joint ventures are created. This would reduce the urgency of the long money problem for domestic entrepreneurs (Radionov 2016).

As practice shows, the full-scale development of Kazakhstan entrepreneurship will require much more time. In general, the globalization of domestic business is fully consistent with the long-term goals of the Kazakhstan2050 strategy to create a highly industrial society based on the principles of a social market economy. In this context, with long-term forecasting, it is advisable to choose the direction of socio-economic foresight until 2050, highlighting the main strategic orientations that determine the functioning of SMEs.

\section{Results}

Currently, many methods are developed for predicting one time series (Rossiter 2015). The purpose of such a forecast is to show what results can be achieved in the future if we move towards it with the same speed or acceleration as in the past. The forecast determines the expected options for economic development based on the hypothesis that the main factors and trends of the past period will be preserved for the forecast period or that can be justified and take into account the direction of their changes in the perspective. A similar hypothesis is advanced on the basis of the inertia of economic phenomena and processes (Sartov 2016).

The predictions based on the extrapolation of the time series can be represented as a specific value of the function:

$$
Y_{t+l}^{*}=f\left(y_{i}, l, a_{j}\right)
$$

where:

$Y_{t+l}^{*}$ - predicted value of a number of dynamics;

$l$ - lead period;

$y_{i}$ - row level taken as extrapolation base;

$a_{j}$ - trend equation parameter.

Having smoothed the time series by the least squares method, we obtain a linear trend dependence of the form:

$$
\hat{Y}_{t}=f(t)
$$

Extrapolation is carried out by substituting into the trend equation the value of the independent variable $\mathrm{t}$, corresponding to the value of the lead (forecast) period. Extrapolation makes it possible to obtain a point value of the forecast, i.e., an estimate of the predicted indicator at a point using the equation describing the trend of the predicted indicator. It is the average estimate for the predicted time interval. The magnitude of the confidence interval of the trend extrapolation is determined as follows: 


$$
Y_{t+l}^{*} \pm K^{*} \cdot S_{y}
$$

where:

$$
t=n, \quad l=1,2, \ldots L
$$

$Y_{t+l}^{*}$ - point forecast at the moment $(t+l)$;

$S_{y}$ - average square error of a trend;

$K^{*}$ - multiplier, determined by the table with a given probability.

The value of $\mathrm{K} *$ depends only on the number of observations (the number of levels of the row $\mathrm{n}$ ) and 1 (the lead period). With increasing $\mathrm{n}$, the values of $\mathrm{K} *$ decrease, and with increasing 1 increase. Consequently, a fully reliable forecast is obtained with a sufficiently large number of observations (for a linear trend, for example, not less than 6 and the lead time is not very long. For the same n, the confidence interval of the forecast increases with increasing 1 .

The standard (root mean square) error in estimating the predicted index Sy is determined by the formula (1.4):

$$
S_{y}=\sqrt{\frac{\sum_{t=1}^{n}(Y-\hat{Y})^{2}}{n-m}}
$$

where:

Y - the actual value of the level;

$\hat{Y} \quad$ - the estimated score of the corresponding indicator for the model;

$\mathrm{n}$ - sample size;

$\mathrm{m} \quad$ - the number of parameters as a function of $\mathrm{f}(\mathrm{t})$.

We illustrate the use of this method on the example of forecasting the indicators of production development of entrepreneurship in the Republic of Kazakhstan. To carry out calculations, we use the data of the time series for the period 2013-2018, presented in Table 4.

Models obtained using regression analysis, allow us to predict the options for the development of economic processes and phenomena, to study the trends in economic indicators, i.e. serve as a tool for science-based predictions. The results of the forecast are the source material for setting real economic goals and objectives, for identifying and making the best management decisions, for developing business and financial strategies in the future (Granberg 2015).

We will conduct a quantitative calculation of the forecast based on formalized forecasting methods, which are based on actually available information on indicators such as: output by all SMEs, mln. Tenge, number of active SME enterprises, units, number of people employed in SMEs, pers. by the extrapolation method for the analytical alignment of the trend, as well as by the exponential smoothing method. 
Table 4. Forecast indicators of entrepreneurship development in the Republic of Kazakhstan

\begin{tabular}{|c|l|l|l|l|}
\hline $\begin{array}{l}\text { Period } \\
\text { number }\end{array}$ & Years & $\begin{array}{c}\text { Forecast of output by all } \\
\text { SMEs, in mln. tenge }\end{array}$ & $\begin{array}{c}\text { Forecast of the number of } \\
\text { active SMEs, in units }\end{array}$ & $\begin{array}{l}\text { Forecast of } \\
\text { employment in } \\
\text { SMEs, in pers. }\end{array}$ \\
\hline $\mathrm{x}$ & & $\mathrm{f}(\mathrm{x})$ & $\mathrm{f}(\mathrm{x})$ & $\mathrm{f}(\mathrm{x})$ \\
\hline 1 & 2013 & 9165412,000 & 69388 & 2576899 \\
\hline 2 & 2014 & 15568081,000 & 79388 & 2810962 \\
\hline 3 & 2015 & 15699405,000 & 178576 & 3183844 \\
\hline 4 & 2016 & 19609010,000 & 192348 & 3166792 \\
\hline 5 & 2017 & 23241125,000 & 211360 & 3190133 \\
\hline 6 & 2018 & 26314313,100 & 2011,783 & 3460415,4 \\
\hline 7 & 2019 & 29533548,600 & 2016,502 & 3553988,02 \\
\hline 8 & $\begin{array}{l}2020 \\
\text { forecast }\end{array}$ & 32191331,513 & 2018,397 & 3621207,916 \\
\hline 10 & $\begin{array}{l}2021 \\
\text { forecast }\end{array}$ & 35962099,182 & 2018,980 & 3780313,323 \\
\hline 11 & $\begin{array}{l}2022 \\
\text { forecast }\end{array}$ & 38992101,328 & 2019,500 & 3923557,48 \\
\hline
\end{tabular}

Source: compiled by authors

We will smooth the time series by one of the main methods of regression analysis - the method of least squares. As a result, we obtain a linear trend dependence of the form (Figure 3, 4, 5):

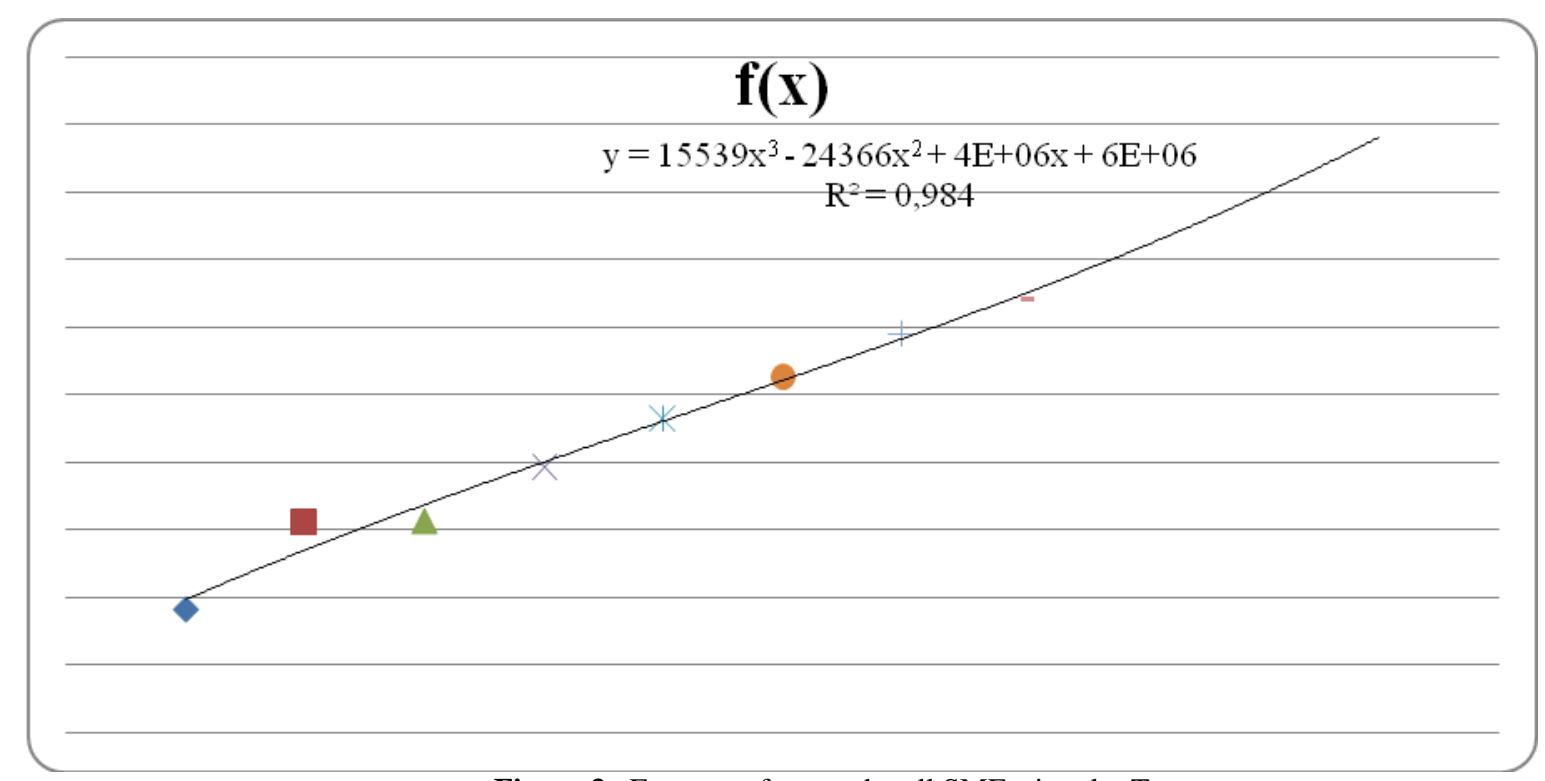

Figure 3. Forecast of output by all SMEs, in mln. Tenge Source: compiled by authors 
Extrapolation is carried out by substituting into the trend equation the value of the independent variable t, corresponding to the value of the lead (forecast) period. The model, on the basis of which the forecast was made, with an accepted probability level of 0.9 , i.e., with a confidence level of $90 \%$, suggests that while maintaining the existing patterns of development, the predicted value falls within the interval formed by the lower and upper bounds. However, if there is not enough reliable a priori information about the patterns of change in the studied economic phenomenon, then a simple extrapolation with the trend can lead to significant errors, as indicated by the Polish statistician Z. Helwig (Bogdanov and Zaitseva 2013).

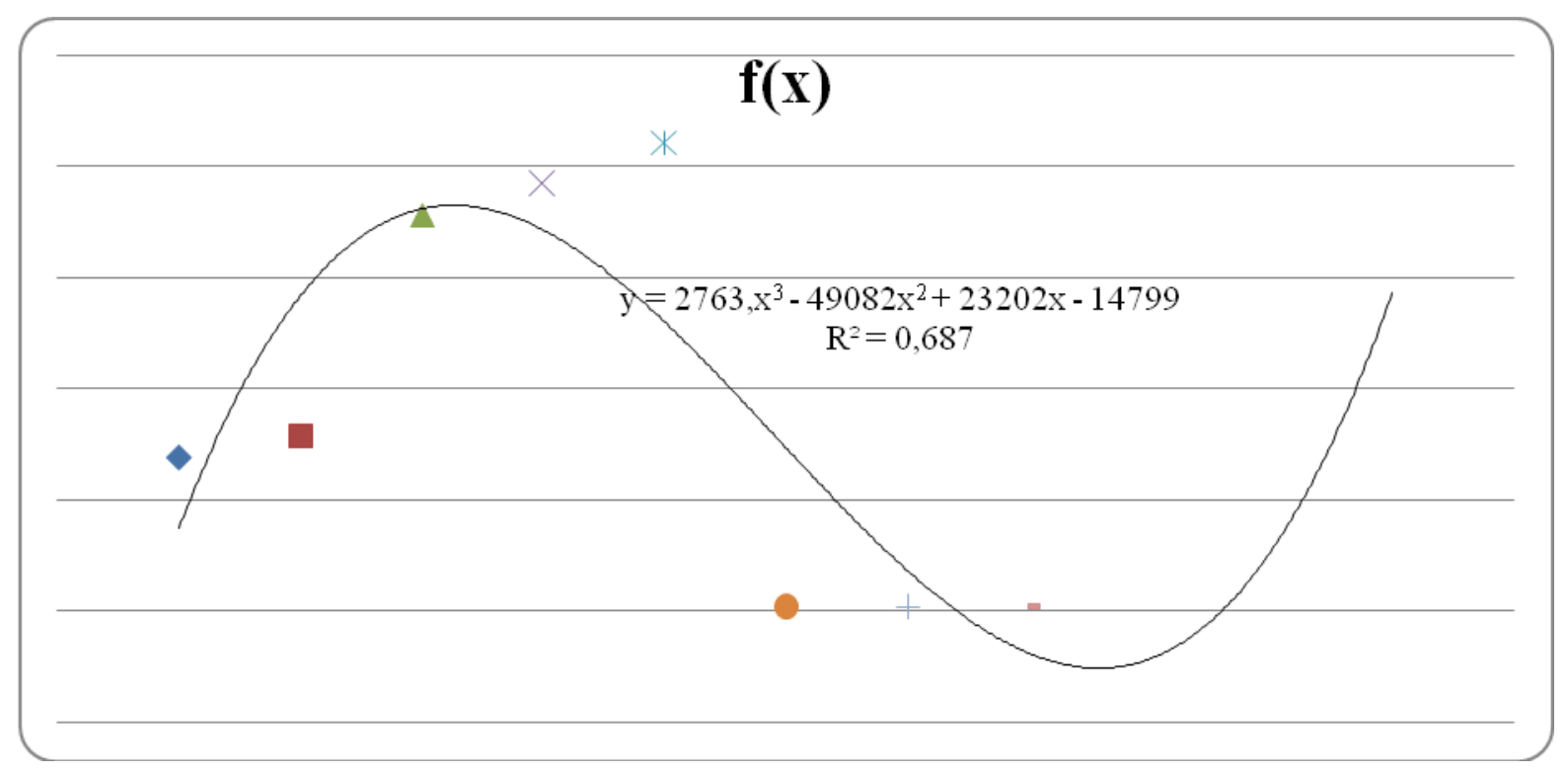

Figure 4. Forecast of the number of active SME enterprises, in units Source: compiled by authors

It should be noted that the extrapolation methods must be applied at the initial stage of forecasting to identify trends in indicators. The main stage of trend extrapolation is the selection of the optimal type of function that describes the empirical series. The task of choosing a function is to select from the actual data xi, yi the form of the dependence (line) so that the deviations i of the data of the initial series yi from the corresponding calculated y'i being on the line are the smallest (Figure 1). After that, you can continue this line and get a forecast. 


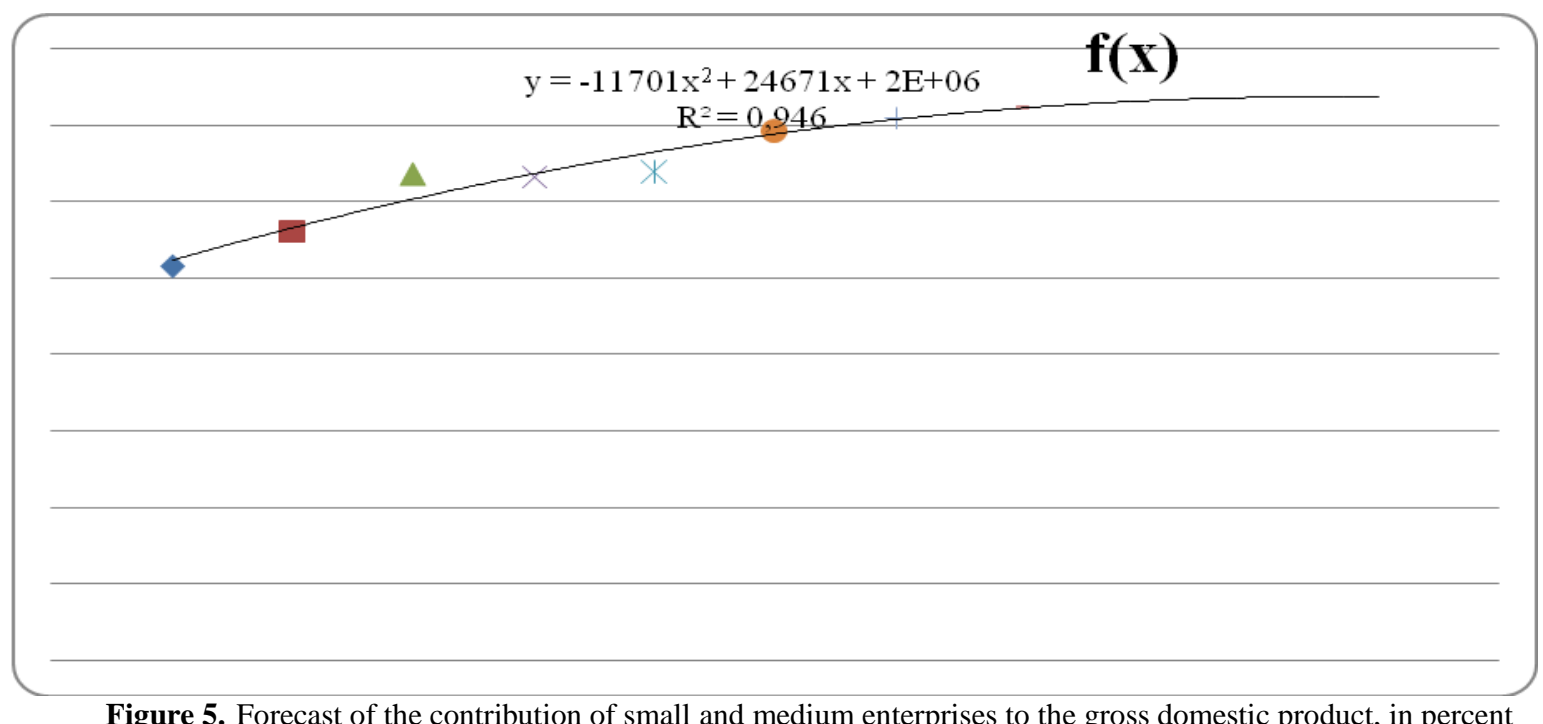

Figure 5. Forecast of the contribution of small and medium enterprises to the gross domestic product, in percent Source: compiled by authors

\section{Conclusions}

Predictive calculation of medium-term indicators of production by all SMEs, the number of active SMEs, the number of people employed in SMEs, conducted by simple extrapolation, shows that production by all SMEs by 2023 will increase almost 2 times compared to 2017. The growth will occur mainly due to the extensive factor the growth in the number of active SMEs, which will grow by $0.3 \%$ over the same period. At the same time, by 2023 , the number of employed will increase by almost 1.3 times, or by 824 thousand people.

Thus, to improve the economic levers of business regulation, it is necessary:

- at the legislative level, to facilitate access to credit loans, to provide tax benefits to commercial banks lending to small and medium-sized enterprises;

- to optimize the taxation of private entrepreneurship, so that the tax burden does not constitute the basis for the liquidation of activities;

- improve the work of leasing companies, provide tax and other benefits to those who provide services to small and medium-sized businesses at low interest rates;

- to attract employment services for financing private entrepreneurship so that their financial resources go not only to the payment of unemployment benefits, but also, for example, to preferential loans to entrepreneurs who help solve employment problems;

- to increase the number of government orders provided by the SMB, and to give this decision the form of the law and monitor its implementation;

- to increase the responsibility of local governments for financial support and development of entrepreneurship, to control the targeted use of funds allocated from the budget for the financial support of small and medium-sized businesses. 


\section{ENTREPRENEURSHIP AND SUSTAINABILITY ISSUES}

ISSN 2345-0282 (online) http://jssidoi.org/jesi/

2019 Volume 7 Number 2 (December)

http://doi.org/10.9770/jesi.2019.7.2(54)

\section{References}

Aimurzina B.T. 2015. Problems of financial support for small medium-sized businesses in Kazakhstan. Transition economy, 3(103), 20-33.

Aimurzina, B., Kamenova, M. 2017. Entrepreneurial Environment in the Current Financial Politics of Kazakhstan. Journal of Advanced Research in Law and Economics. Romania, 4(26), 1371-1374.

Aimurzina, B., Kamenova, M., Omarova, A. 2018. State Tax Management: Gurrent Status and Mechanism of Improvement. Descrierea CIP a Bibliotecii Naţionale a României-Craiova: ASERS Publishing. Romania. ISBN 978-606-8689-35-7.

Babich, S. 2016. Role of small business abroad. Consultant Director, 1(5), 75-78.

Bogdanov, E.I., Zaitseva, N.A. 2013. Analysis and diagnostics of the financial and economic activities of the enterprise. Almaty: LEM. $361 \mathrm{p}$.

Baltgailis, J. 2019. The issues of increasing the effectiveness of teaching comparative economics, Insights into Regional Development 1(3): 190-199. https://doi.org/10.9770/ird.2019.1.3(1)

Bulatov, A.Zh. 2018. The financial sector and its capabilities in the development strategy of Kazakhstan. Astana 210 p.

Cichy J., Gradoń W. 2016. Innovative economy, and the activity of fi nancial market institutions. Case of Poland, Journal of International Studies, 9(1), 156-166. https://doi.org/10.14254/2071-8330.2016/9-1/11

Granberg, A.G. 2015. Dynamic models of the national economy. Moscow: Economics. 240 p.

Ivanová E., Masárová J. 2016. Assessment of innovation performance of Slovak regions, Journal of International Studies, 9(2), 207-218. https://doi.org/10.14254/2071-8330.2016/9-2/16

Kaldybaev, O.K., Bayzakov, S.B. 2017. Mathematical methods in planning and managing the regional economy. Almaty. 160 p.

Khusainov, M.K., Isokov, A.A. 2012. The study of foreign experience in financing and supporting small and medium-sized enterprises. Journal of Economics and Law, 2 (9), 34-3

Kowo, S. A., Adenuga, O. A. O., Sabitu, O.O. 2019. The role of SMEs development on poverty alleviation in Nigeria, Insights into Regional Development, 1(3), 214-226. https://doi.org/10.9770/ird.2019.1.3(3)

Krpálek, P., Krpálková Krelová, K. 2016, Possibilities for Developing Business Potential in Economic Education. Examples of Implementation in Slovakia and the Czech Republic, Economics and Sociology, 9(4), 119-133. https://doi.org/10.14254/2071$\underline{789 X .2016 / 9-4 / 7}$

Mamedov, O., Movchan, I., Ishchenko-Padukova, O., Grabowska, M. 2016, Traditional Economy: Innovations, Efficiency and Globalization, Economics and Sociology, 9(2, 61-72. https://doi.org/10.14254/2071-789X.2016/9-2/4

Nazarbayev, N.A. 2017. Message from the President of the Republic of Kazakhstan to the people of Kazakhstan. The Third Modernization of Kazakhstan: Global Competitiveness.

Newman, W., Mwandambira, N, Ongayi, W. 2018. Literature review on the impact of tax knowledge on tax compliance among small medium enterprises in a developing country. International Journal of Entrepreneurship, 22(4), 1939-4675-22-4-217

Radionov, Zh. K. 2016. Financial aspects of ensuring the competitiveness of the enterprise. Moscow. 189p.

Rossiter, J. R. 2015. Competitiveness Management. SPb.: Science. 656 p.

Sartov, U.K. 2016. Fundamentals of financial management. Almaty: LEM. 114 p. 


\section{ENTREPRENEURSHIP AND SUSTAINABILITY ISSUES}

ISSN 2345-0282 (online) http://jssidoi.org/jesi/

2019 Volume 7 Number 2 (December)

http://doi.org/10.9770/jesi.2019.7.2(54)

Skala, V.I., Skala, B.V. 2012. Individual business in the Republic of Kazakhstan. Almaty: LEM Publishing House LLP. 236p.

Statistics Committee of the Ministry of National Economy of the Republic of Kazakhstan. 2018. http://www.stat.kz

Vaculík, M., Pászto, V., \& Švarcová, B. 2017. Spatial distribution of innovation activities in Czech Republic, 2010-2012. Journal of International Studies, 10(1), 123-134. https://doi.org/10.14254/2071-8330.2017/10-1/8

Zizlavsky, O. 2016. The Use of Financial and Nonfinancial Measures within Innovation Management Control: Experience and Research, Economics and Sociology, 9(4), 41-65. https://doi.org/10.14254/2071-789X.2016/9-4/3

Roza SHOKAN is Candidate of Economic Sciences L.N.Gumilyov Eurasian National University, Astana, Kazakhstan. Research interests: economy, investments, banks.

ORCID ID: orcid.org/0000-0002-1005-3769

Ainur KARIPOVA is Candidate of Economic Sciences L.N.Gumilyov Eurasian National University, Astana, Kazakhstan. Research interests: entrepreneurship, investment, budget, taxes.

ORCID ID: orcid.org/0000-0003-4376-9074

Aizhan KHOICH is Candidate of Economic Sciences, L.N.Gumilyov Eurasian National University, Astana, Kazakhstan. Research interests: small business, competition, competitive environment, entrepreneurship

ORCID ID: orcid.org/0000-0002-0128-3052

Gulmira KABDULLINA is Doctor of Economic Sciences, Professor of South Ural State University (National Research University), Chelyabinsk, Russia. Research interests: investment, innovation, human resources, конкурентная среда, предпринимательство

ORCID ID: orcid.org/0000-0002-0215-1502

Nuradin KUDAIBERGENOV is Candidate of Economic Sciences Kazakh Ablai Khan University of International Relations and World Languages, Almaty, Kazakhstan. Research interests: economy, state, investments, financing.

ORCID ID: orcid.org/0000-0003-1039-2530

Gaukhar NIYETALINA is Candidate of Economic Sciences «Turan» University, Almaty, Kazakhstan. Research interests: production, consumption, investment, capital.

ORCID ID: orcid.org/0000-0002-2004-0603

Copyright (C) 2019 by author(s) and VsI Entrepreneurship and Sustainability Center

This work is licensed under the Creative Commons Attribution International License (CC BY).

http://creativecommons.org/licenses/by/4.0/

(c) (i) Open Access 